\title{
O DISCURSO TEOLÓGICO COMO DISCURSO CONSTITUINTE
}

Jarbas Vargas NASCIMENTO ${ }^{1}$

\section{CONSIDERAÇÕES INICIAIS}

Já há algum tempo que Maingueneau (1993, 2000, 2004, 2006, 2010, 2015) propôs e vem ampliando discussões acerca da categoria de discursos constituintes como uma proposta de programa de pesquisa, que o autoriza a agrupar discursos que tematizam sua própria constituição. Trata-se de discursos primeiros, fundadores, uma vez que carregam em si o princípio de uma coletividade e avalizam diferentes gêneros de discurso. Nessa categoria, enquadram-se o discurso literário, o filosófico, o científico e o religioso. A lógica que leva o autor a juntar esses discursos se sustenta no caráter constituinte, que lhes garante uma autoridade individualizadora e a todos os seus enunciados. É o próprio Maingueneau (2000, p. 6) que esclarece, ainda, "que o estatuto de discurso constituinte é de fundar e de não ser fundado. Ele é ao mesmo tempo auto e heteroconstituinte, duas faces que se supõem reciprocamente”.

Com base no que antecede, este capítulo tem como foco o questionamento da constituência do discurso religioso, conforme hipotetiza e postula Maingueneau \& Cossutta (1995) e o reconhecimento da constituência do discurso teológico, não incluído pelo autor no quadro dos discursos constituintes. A questão principal não é apenas inserir o discurso teológico entre os constituintes, mas transferir o domínio específico da produção discursiva teológica para o quadro dos discursos constituintes, pois reconheço a constituência desse discurso e não do religioso, que se funda no teológico, legitimando-o em um espaço institucional. Isso se deve à observação de seus dispositivos de comunicação, que conferem sentidos às ações da humanidade, às suas condições de possibilidade de funcionamento discursivo, que me facultam apreender o teológico como fundador de si mesmo e de outros gêneros de discurso.

1 E-mail: jvnf1@yahoo.com.br 
Quero esclarecer que entendo o discurso religioso como um discurso institucional $^{2}$, na medida em que esse tipo de discurso propõe uma relação de poder, sustenta-se pelo controle e imposição sobre os fiéis, a fim de alcançar bens simbólicos, conforme afirma Bourdieu (1989). Para mim, o discurso religioso constitui um quadro de referência obrigatório aos posicionamentos ideológicos, enquanto o discurso teológico, ao contrário do religioso, encena particularidades enunciativas e funda-se em estruturas míticas de natureza ontológica incontestáveis, que validam outros tipos de discurso, garantindo-lhe legitimidade. Grosso modo, considero que, no domínio do teológico, a realidade primeira e última, Deus, é quem funda sua própria existência e a do Outro no/ pelo discurso. A oposição entre o discurso religioso e o teológico parece-me estar relacionada ao modo como se organizam as coisas do mundo social e à ruptura da percepção comum desse mundo, para evidenciar a transcendência da relação entre o empírico, a humanidade e Deus, fonte de fé. Trata-se, na verdade, de distinguir o transcendente e os processos de transformação socioculturais visados pela fé, ou seja, o teológico e o religioso.

Para fundamentar minha posição, elejo a Análise do Discurso de linha francesa (AD), pois essa disciplina permite posicionar-me criticamente neste debate epistemológico e responder ao problema de pesquisa que proponho, de modo particular, enfocar o discurso teológico como uma produção verbal extremamente importante em nossa sociedade. Uma premissa básica na qual se pauta minha reflexão é admitir a dimensão crítica que me impõe a $\mathrm{AD}$ e sua interdisciplinaridade constitutiva, cujo objeto - discurso - carrega uma função, que se abre a um diálogo fértil com a Teologia, motivando-me a ampliar discussões nos campos da Linguística e no da Teologia.

$\mathrm{Na}$ verdade, Linguística e Teologia, embora distintas em seus campos, cada um desses domínios do conhecimento se adequa aos critérios específicos de cientificidade exigidos pela comunidade discursiva científica, mas há uma particularidade que faço questão de destacar. Desde sua constituição, na década de 1960, a AD surge interdisciplinar e tem reivindicado dos analistas, durante o percurso de seu desenvolvimento, interesses e pactos por diferentes textualidades, entre elas, as dos campos da Ciências, da Literatura, da Filosofia, da Religião e da Teologia, que devem ser considerados em seus modos específicos de produção e de circulação. Vale ressaltar também, que diversas abordagens das Ciências Humanas, devido aos procedimentos metodológicos que operacionalizam, muitas vezes, desconsideram a relação entre as causas primeiras e as últimas. Por isso, por

2 Instituições são mecanismos de ordem social, reguladores do comportamento humano em determinada sociedade com função comunitária, que transcende os indivíduos e mediam regras comportamentais. 
conta dos processos de abstração e de generalização ignoram a fé, colocando-a fora de seus próprios questionamentos, ao incluí-la apenas no campo da Religião, nos domínios da instituição e da cultura. Nesta perspectiva, afastam-se da fé, que se funda sobre o mistério de Jesus, para somente apreender o fenômeno religioso. Por isso, enfatizo a pertinência e a relevância de meu posicionamento crítico frente ao questionamento de inclusão do discurso religioso no quadro dos constituintes. Para Gabus (1969, p.83),

a pessoa, a obra e o ensinamento de Jesus Cristo constituem não somente o fato central e decisivo que nos dá um sentido à nossa existência humana, mas também confrontam-nos no próprio mistério dessa existência a uma realidade última que chamamos Deus e que funda essa existência.

Para Gabus, no Cristo tornado homem, descobrimos nossa humanidade, pois ele é um homem bodas livre, criador, comprometido com todos e com o mundo.

Os objetivos que busco alcançar, neste capítulo, são comprovar a constituência do discurso teológico, pois ele se propõe como uma fonte legitimadora, que se autoriza a si mesmo; verificar a relação interdisciplinar da AD com a Teologia, de cujas abordagens destacam-se aspectos de instauração discursiva. Além disso, objetivo identificar, no discurso As bodas de Caná da Galileia, um investimento no código linguageiro, na cenografia e no ethos discursivo, que se articulam, na cenografia, para suscitar a adesão do co-enunciador, ao inscrevê-lo em uma instituição discursiva, que legitima o teológico, como uma prática enunciativa da sociedade.

Após essas considerações iniciais, organizo minhas reflexões, a partir dos seguintes tópicos: situando a problemática do debate, apresentação de dados teórico-metodológicos da $\mathrm{AD}$, enfocando categoria de discursos constituintes e das noções de cenografia, ethos discursivo, o código linguageiro, e a noção de hiperenunciador, como recursos enunciativos fundamentais aos discursos constituintes. A seguir, procedo à análise do texto selecionado, tratando daquilo que é o eixo central deste capítulo, a saber, a constituência do discurso teológico.

\section{SITUANDO A PROBLEMÁTICA DO DEBATE}

Parto do pressuposto de que o discurso religioso se configura como um discurso institucional e que, por isso, seja possível afirmar que o lugar de onde o enunciador enuncia, nesse tipo de discurso, filia-o à instituição que ele pertence e/ou representa. Para fundamentar o que acabo de dizer, sirvo-me da reflexão de Sales \& Haetinger, quando afirmam que 
a religião é considerada uma instituição, pois é constante ao longo da história e exerce um padrão de controle da sociedade e uma programação da conduta individual. Ela apresenta características próprias das instituições sociais: é socialmente coercitiva; é exterior aos indivíduos; possui objetividade, historicidade e detém autoridade moral. (s/d, p.3)

$\mathrm{Na}$ verdade, a Religião se estabelece como instituição, ou seja, uma construção social, que visa a estabelecer a ordem moral e consolidar uma função social, situando nas manifestações sociais, que operam na organização humana. Dentro dos limites do mundo, ela se manifesta necessária à sobrevivência humana, pois é o próprio homem que cria as bases para a sua permanência. Nesse sentido, a Religião, criada pelo próprio homem, se comporta como instrumento regulador e normativo das ações humanas, com o objetivo de validar a si mesma com suas leis e exigências reconhecidas pela sociedade.

Embora alguns estudiosos critiquem Durkheim, sua contribuição é fundamental para a Sociologia da Religião, pois que para ele

a religião é um sistema solidário de crenças e de práticas relativas a entidades sagradas, ou seja, separadas, interditas; crenças e práticas que unem em uma mesma comunidade moral, chamada Igreja, todos os aderentes. (DURKHEIM, 1996, p.59)

Não podemos negar também a influência de Durkheim, quando afirma que a religião cumpre um papel social e, por isso, ela é concebida como um sistema de crenças e práticas que, embora envolva o sagrado, carrega as características de uma instituição. Desse modo, cada Religião mostra o caminho experiencial que deve ser seguido por cada um de seus adeptos. Outro ponto a destacar é que a Religião pode excluir deliberadamente qualquer referência a Deus ou ao sobrenatural, como ocorre com algumas religiões, entre elas o Budismo (SCOTT, 2006, p.171). Sabemos que muitos conceitos de Religião se adequam apenas às culturas ocidentais, faltando, por conseguinte, uma concepção mais abrangente e que não leve a um preconceito religioso, considerando uma Religião melhor ou superior à outra.

Uma outra reflexão que me parece bastante esclarecedora em Durkheim diz respeito ao papel integrador que a Religião estabelece com a sociedade, assim como o patriotismo e o nacionalismo, superando as diferenças ideológicas, a fim de comungar valores universais com a fé. Do ponto de vista sociológico, o fato de a Religião ser integradora facilita o equilíbrio social, harmoniza as relações humanas e sociais, permitindo um funcionamento social adequado frente às questões tensas que assolam a sociedade (GIDDENS, 1994). 
Dada a complexidade do tema que aqui trato, esclareço que minha reflexão não esgota a problemática levantada por Maingueneau (2000, 2004, 2006, 2010, 2015) sobre os discursos constituintes, mas abre possibilidade de empreender um estudo crítico-analítico, fundamentando-me nos argumentos sugeridos pelo próprio autor, ao incluir no quadro dos constituintes o discurso religioso e não o teológico. Não há como confundir o objeto teológico, ou seja, da revelação divina, com o religioso, as estruturas humanas institucionalizadas. A presença das instituições em nossa sociedade supõe uma comunidade discursiva, que possibilite a manifestação e a transmissão de crenças e de comportamentos, que organizam as instituições, fazendo-as elaborar seu próprio discurso (KRIEG-PLANQUE, 2014).

Não cabe aqui ampliar o debate sobre a Religião e a Teologia, principalmente em função da complexidade que essa questão traz para a fé. Meu interesse é distinguir discurso religioso e discurso teológico, sem esquecer que tanto um como outro ocupam-se da palavra e transitam entre a linguagem e o mundo. Por esse motivo, a tensão entre esses dois tipos de discurso é o que me leva a questionar a não inclusão do teológico no quadro dos constituintes, conforme Maingueneau \& Cossutta (1995). É isso que considero fundamental nesse capítulo, posto que o discurso religioso e o discurso teológico constituem espaços discursivos abertos a questionamentos, cujas respostas ampliam o quadro problemático dos discursos constituintes.

Alguns autores consagrados da Sociologia se preocupam em compreender a sociedade, a partir da Religião e de fenômenos religiosos e abrem caminhos para o entendimento da institucionalidade do discurso religioso. Certamente, esses estudos podem dialogar com os da AD, nas perspectivas de Maingueneau e, por conta disso, sou levado a adotá-los no cotejo que faço entre o discurso religioso e o teológico para comprovar a constituência do teológico. Nesse sentido, reconheço que o aparato teórico-metodológico da $\mathrm{AD}$ em diálogo com o da Sociologia da Religião e da Teologia me possibilitam, então, aplicá-los na análise do texto, As bodas de Caná da Galileia, retirado do evangelho de João 2,1-11, materialidade selecionada do campo teológico. Considero, em função dos objetivos que aqui proponho, um material de análise relevante, pois que o apreendo como discurso, acionando Charaudeau (2011, p.4), quando argumenta que

o discurso, como lugar, ao mesmo tempo, de estruturação dos usos em função das condições de produção nas quais esses usos se manifestam, relacionados a comportamentos linguageiros dos sujeitos falantes, e categorizações de sentido relacionadas a sistemas de conhecimento e de crença aos quais aderem os indivíduos ou grupos sociais. [...], uma vez que o sentido de 
discurso resulta de uma multiplicidade de fatores de ordem contextual, que fazem com que o sentido não seja observável em nenhuma das unidades que compõem uma produção discursiva qualquer, e só pode ser inferida pelo jogo de combinações de todos esses fatores.

Escolhi esse material linguístico como corpus, pois ele se organiza em meio às condições sócio-histórico-culturais de sua produção, investe no código linguageiro dos sujeitos que se movem na cenografia para enunciar, reflete efeitos de sentido decorrentes de conhecimentos e crenças, que podem ser inferidos no funcionamento desse discurso e transita na fronteira entre o dizível e o indizível. Ressalto, ainda, que o código linguageiro simbólico, próprio ao discurso teológico produz um efeito de distanciamento conceitual, resulta em efeitos de sentido, que desvelam uma condição paratópica em seu processo criador, caracterizando, dessa maneira, um discurso constituinte (MAINGUENEAU, 2000). Ao selecionar As bodas de Caná da Galiléia, é importante que fique claro que compartilho com os estudiosos que advogam ser o corpus um objeto de pesquisa, constituído em função de pressupostos teórico-metodológicos e meu posicionamento.

Meu gesto de leitura se fundamenta na AD e particulariza o espaço discursivo teológico e é, nesse espaço, que inscrevo o debate que proponho: comprovar o traço constituinte do discurso teológico, a partir de seu modo de inscrição discursivo. Julgo importante afirmar que, na literatura sobre o discurso religioso, há um certo consenso de que esse tipo de discurso se organiza pela interdiscursividade com o teológico, apoia-se nele no processo de seu funcionamento argumentativo-enunciativo e vale-se dele como fonte para a construção de seus enunciados. Por esse mecanismo de engendramento discursivo, ao fundar-se sobre o teológico, o enunciador, no discurso religioso, constrói um processo enunciativo, que supõe o espaço do teológico, a fim de imprimir efeitos de verdade e de credibilidade, nas práticas discursivas, que enuncia.

Não posso deixar de lembrar que, já em Orlandi (1983), há uma tentativa de diferenciação entre o discurso religioso e o discurso teológico. $\mathrm{Na}$ ocasião, a autora conceitua o discurso religioso, como informal e como um tipo de discurso em que há uma relação espontânea com o sagrado. Para ela, o discurso religioso se constitui pela interdiscursividade com o teológico que, segundo sua proposta, se caracteriza como um tipo de discurso cuja mediação entre o humano e o sagrado se faz por uma sistematização dogmática das verdades religiosas. Para ela, o discurso religioso

é aquele em que há uma relação espontânea com o sagrado" sendo, portanto, "mais informal"; enquanto o teológico é o tipo de discurso em que a 
mediação entre a alma religiosa e o sagrado se faz por uma sistematização dogmática das verdades religiosas, e onde o teólogo (...) aparece como aquele que faz a relação entre os dois mundos: o mundo hebraico e o mundo cristão, sendo, assim, mais formal. (ORLANDI, 1983, p. 246, 247)

Embora as reflexões de Orlandi tenham sido produtivas para a distinção entre o religioso e o teológico, não foram totalmente suficientes para o tratamento desta questão (NASCIMENTO, 1993). Entretanto, não se trata aqui de rejeitar as contribuições de Orlandi, mas de enaltecê-la por ter trazido para discussão uma questão que ultrapassa os limites específicos da Linguística, mas que dialoga com ela, posto que me ajuda a reivindicar a inclusão do discurso teológico no quadro dos discursos constituintes e valorizar a hipótese de Maingueneau.

\section{A ANÁLISE DO DISCURSO DE LINHA FRANCESA E A CATEGORIA DISCURSOS CONSTITUINTES}

A falta de discussões mais aprofundadas sobre a problemática que configura os discursos constituintes, conforme postulam Maingueneau \& Cossutta (1995) e, posteriormente, Maingueneau $(2000,2004,2006,2010,2014)$ e a complexidade que envolve os estudos sobre os discursos religioso e o teológico representam para a $\mathrm{AD}$ um amplo território de pesquisa para essa categoria e para os campos discursivos teológicos e da religiosidade. Embora Maingueneau enquadre na categoria de constituintes o literário, o religioso, o científico e o filosófico, maior atenção deu ao discurso literário, privilegiando-o, a partir das relações entre identidade enunciativa, a funcionalidade do texto literário e o processo criador. Como o próprio Maingueneau sugeriu ser uma proposta, julgo necessário que ela seja repensada.

A base teórico-metodológica, que adoto, exige, de partida, a inserção desse tema no contexto da $\mathrm{AD}$, prática crítica com a qual estou envolvido e que se define como uma disciplina de entremeio e pouco homogênea. Apesar de seu caráter pouco homogêneo e perspectivas tensas com determinados pesquisadores, nada impede a utilização dessa disciplina para comprovar a constituência do discurso teológico.

Justifico minha escolha pela $\mathrm{AD}$, pois que seu aparato teórico-metodológico possibilita diálogo entre a Religião e a Teologia, em suas particularidades na produção de discurso e, porque, no funcionamento desses discursos, emergem dados sócio-históricos e investimentos ideológicos, que se materializam na textualidade e nas instâncias subjetivas, que se movimentam nessas práticas discursivas. Concentro, nesse instante, minhas reflexões, particularmente, na categoria de discursos constituintes, porque pretendo elucidar a contestação que proponho, na me- 
dida em que certos pontos relativos às considerações teóricas propostas por Maingueneau permitem-me outorgar ao discurso teológico um papel fundador.

A AD surge, na década de 1960, na França, em meio a discussões políticas e de ensino em que Pêcheux (1938-1983) e Dubois (1020-2005), aproveitando o declínio do Estruturalismo, configuram um novo campo de estudo, cujo objeto denominaram discurso e cuja abrangência implicava conceitos advindos do Materialismo Histórico, da Psicanálise e da Linguística, integrando os fenômenos histórico-sociais, a subjetividade enunciativa e o acontecimento linguístico. Desse modo, o impulso epistemológico proposto por Pêcheux e Dubois organiza-se pela interdisciplinaridade e funda em uma perspectiva linguística, que articula a linguagem às condições sócio-históricas de sua produção e ao sujeito. Institui-se, por conseguinte, o discurso como objeto dessa nova disciplina.

As mudanças frequentes na Linguística e nas demais Ciências Humanas e nas Ciências Sociais impulsionaram grandes transformações na trajetória da $\mathrm{AD}$, consolidando-a, na atualidade, como disciplina no interior da Linguística e da Comunicação. Cabe-me observar a forma como essa disciplina vem operando, principalmente, se considerar a incorporação de aspectos pragmáticos, enunciativos, socioculturais e linguístico-estilísticos como constitutivos da noção de discurso. De fato, a AD ocupa, hoje, um espaço privilegiado no cenário da Linguística, pois assume o discurso sob um ponto de vista linguístico como articulação de um texto e de um lugar social do qual ele é produto. Na verdade, a AD se diferencia de outras disciplinas por "relacionar a estruturação dos textos aos lugares sociais que os tornam possíveis e que eles tornam possíveis" (MAINGUENEAU, 2015, p.47). Todavia, faz-se necessário entender que a noção de lugar social não se refere ao lugar empírico, mas às posições que o sujeito ocupa no discurso. Ainda que muitos pesquisadores utilizem o rótulo de Análise do Discurso em suas pesquisas, poucas vezes se enquadram no constructo teórico-metodológico que a $\mathrm{AD}$ requer e comportam-se distantes dos analistas do discurso, devido à polissemia do termo discurso e à condição empírica de sua apreensão e da disciplina que o dispõe como seu objeto (MAINGUENEAU, 2007).

Embora reconheça a complexidade e as dificuldades de a Teologia adentrar nessa configuração teórico-metodológica, pois pode trazer dificuldades de fé, faz-se necessário que ela esteja inserida nesse novo contexto sociocultural e consiga se deslocar, traduzir-se a si mesma, transformar-se. Libanio \& Murad (2005) advertem os teólogos a repensarem a fé em uma perspectiva histórica e, em tempos de pluralismo, ponderarem a necessidade de a Teologia servir-se da diversidade de orientações para o alcance de uma homogeneidade teológica. Esse deslocamento intelectual reorganiza os diferentes tipos de conhecimento e incita um diálogo entre diferentes campos do conhecimento, principalmente com a $\mathrm{AD}$, que 
constitutivamente abre um espaço para o diálogo no interior dessa nova atitude de disciplinamento epistemológico, na medida em que resulta de relações articuladas de diferentes conhecimentos, que se encontram em complementariedade.

Tomo como foco de atenção, nesse momento, a categoria discursos constituintes, o que exige, inicialmente, uma contextualização. Como explica Maingueneau (2000), os discursos constituintes se projetam como Absolutos e buscam para si uma espécie de transcendência. Obviamente, essa categoria de discursos difere de outras, pois, sendo constituintes, se autorizam a si próprios, pertencem ao thesaurus, são hierarquizados como discursos-fonte e, em consequência, regulam o surgimento de outros discursos. Nesse sentido, o programa de pesquisa sobre os discursos constituintes, da forma como é proposto por Maingueneau \& Cossutta (1995) se fundamenta na perspectiva de que certos tipos de discurso se concebem fundadores de outros discursos, não admitem posição hierárquica superior a deles; por isso, legitimam a si e os demais discursos. A apreensão da constituência dos discursos literário, religioso, científico e filosófico se dá por meio de dimensões indissociáveis em que, de um lado, atribui-se à constituência a marca de um processo pelo qual esses discursos regram sua própria emergência no interdiscurso e, por outro lado, como seus modos de organização garantem-lhes uma totalidade textual (MAINGUENEAU, 2008).

Pela observação das duas dimensões apresentadas, resgato em Maingueneau (2008) aspectos essenciais dos discursos constituintes e que, certamente, cabem ao teológico, e que utilizarei no momento da análise, para respaldá-la. Ressalto o fato de os discursos constituintes conferirem a seus enunciados particularidades, tais como, em seu modo de dizer o que dizem, em sua forma de fazer circular seus enunciados e a especificidade da interação que estabelecem com o co-enunciador. Reforçando a premissa de que a noção de discursos constituintes seja uma hipótese, um programa de pesquisa, o próprio Maingueneau nos adverte sobre a dificuldade de manejá-los, principalmente, quando se observam os quatro tipos de discurso e percebem-se as diferentes formas pelas quais cada um evidencia sua constituência. De qualquer maneira, posso dizer que é a enunciação e a emergência da imagem dos sujeitos que se movem, na cenografia, que asseguram a legitimação dos discursos constituintes.

De outra parte, Maingueneau (2008) postula que os discursos constituintes operam uma função simbólica na sociedade, que lhes permite, por meio de símbolos, a representação de acontecimentos fora de seu campo real de percepção. Para esclarecer essa função, Maingueneau utiliza o termo archeion, cuja carga semântica remete a uma relação com arquivo que, para Paes (2002), é um conjun- 
to de textos ou materialidades simbólicas preservados, autofundantes e fonte de autoridade e memória. Por isso, esses discursos simbolizam o cosmos e constroem uma enunciação que o representa em sua configuração simbólica e textual. Observo, portanto, que a apreensão do termo archeion visa a enfatizar o caráter fundante, o valor cultural e o poder de autoridade que os discursos constituintes herdam e atribuem a si mesmos como base primeira do conhecimento histórico.

Uma importante particularidade aqui é o caso de Maingueneau pensar os discursos constituintes como discursos-limite. Esta consideração apoia-se no fato de que a enunciação, nesses tipos de discurso, construída textualmente, implica o estatuto fundador, principalmente pelo espaço e tempo enunciativos. O propósito de sua produção dos discursos constituintes carrega um tempo e um universo social particular que os conduzem a sucessivos espaços de conflitos entre os posicionamentos materializados, na enunciação, e seu modo de organização textual.

Ao comentar sobre os diferentes investimentos dos discursos constituintes, Maingueneau (2000) oferece a chave de entrada para a análise desses discursos, requisitando a necessidade de operacionalização de dispositivos enunciativos, que intervêm na instauração e validação que esses discursos efetivam. Assim, facilmente se comprova, nesses discursos, o investimento na cenografia como um lugar de representação de sua própria enunciação, no código linguageiro, como registro linguístico prescritivo de sua produção, visando à negociação de efeitos de sentido e no ethos discursivo, entendido como uma estratégia mobilizada pelo enunciador, para se dizer e mostrar-se, ou seja, apresentar-se a si mesmo ao co-enunciador e validar seu modo de enunciar.

Ainda no contexto dos discursos constituintes, Maingueneau (2006) propõe a categoria paratopia que, para ele, é uma condição particularizante desses discursos. O argumento do autor esclarece que a noção de paratopia é, de um lado, problemática, pela cenografia engendrada e pelo enunciador, que se diz em uma encenação que lhe dá corpo, adotando-o como fiador de uma fonte legitimadora de pertencimento e não pertencimento ao mundo. Por outro lado, ela é uma categoria produtiva, porque permite que o co-enunciador se integre à comunidade discursiva do enunciador.

Por isso, a paratopia se instaura como um pertencimento paradoxal, entre um lugar e um não-lugar, que eles fundam. Isso não quer significar, para Maingueneau, que esses discursos não pertençam a um lugar, mas que sua des- localização é que os legitimam e impossibilitam sua estabilidade. Assim, essa condição explícita dos discursos constituintes não se manifesta como uma unidade tópica nem atópica, mas por uma natureza paratópica, por meio de um sujeito criador que, por si mesmo, funda, constrói e assume uma identidade criadora. 
A natureza paratópica do discurso teológico designa o lugar de onde ele enuncia para se dizer. $\mathrm{Na}$ verdade, o discurso teológico como os outros discursos constituintes definem seu próprio lugar do dizer, ao enunciar. Por isso, posso dizer que, enquanto o discurso religioso é validado por uma instituição em função do posicionamento de seus atores, o discurso teológico se constitui como um ato enunciativo fundante, uma realidade única não objetivada pelo discurso religioso. Além disso, segundo Maingueneau, o criador aparece como alguém que não tem lugar para estar e que deve construir seu próprio espaço enunciativo por essa mesma impossibilidade de dizer.

Com base nessas questões que apontei acima, busco, ainda, em Maingueneau (2006), diferentes ocorrências de paratopia, lembrando, entretanto, que distinção em tipos de paratopia se justifica apenas didaticamente e em função de clareza na organização do discurso. De fato, os discursos constituintes interferem-se mutuamente e cumulam seus efeitos, principalmente em relação à sua condição paratópica. Maingueneau (2006) sugere, para isso, os seguintes tipos de paratopia, a partir da observação de seu enunciador, a saber, paratopia de identidade, que se refere ao afastamento e/ou negação de pertencimento a um grupo; paratopia espacial, quando o lugar não é o lugar do sujeito no discurso; paratopia temporal, quando é marcada pelo anacronismo; paratopia linguística, quando o multilinguismo participa e/ou interfere na criação: minha língua e a língua do outro; paratopia criadora, pois que a paratopia se integra necessariamente ao ato criador. Assim, o criador particulariza seu modo de enunciar pelo laço que estabelece no exercício da Filosofia, da Literatura, da Ciência ou da Teologia.

Em síntese, posso argumentar que o regime paratópico condiciona os discursos constituintes e interfere no processo criador. Por isso, a paratopia criadora "é aquilo que se precisa ficar livre por meio da criação e aquilo que a criação aprofunda; é a um só tempo aquilo que cria a possibilidade de acesso a um lugar e aquilo que proíbe todo pertencimento" (MAINGUENEAU, 2006, p.109). Disso decorre o argumento que a paratopia é condição do discurso teológico e a condição do ato criador do enunciador teológico. Logo, o discurso teológico parece-me integrar o regime dos constituintes e um dos argumentos é o caráter problemático de seu enunciador, o que justifica meu questionamento.

Desse modo, no discurso teológico que analiso, concebe um único criador e vários enunciadores; por isso, observo a voz do evangelista, de outros enunciadores e a voz de Jesus, por meio do evangelista, que o revela um hiperenunciador, que funda o thesaurus bíblico. No discurso teológico, o evangelista João coloca em evidência os enunciados que identificam Jesus, permitindo que o hiperenunciador se mostre por sua palavra. Uma estratégia para mostrar que Jesus está 
habitado por ele. Esse processo corresponde a uma condição paratópica criadora, na medida em que a enunciação se constitui pela impossibilidade de o enunciador atribuir a si um lugar que define sua criação problemática, seu próprio pertencimento ao capo teológico e à sociedade. O discurso teológico se organiza não pelas falas que emanam de seus produtores - evangelistas etc., mas diretamente de Deus, ao autor por excelência. Esses produtores são apenas porta-vozes do único e verdadeiro enunciador, que os inspira e legitima o discurso. Isso valida a paratopia que torna possível o discurso teológico, que instaura um processo criador paratópico, na medida em Jesus é o responsável pelo discurso que ele mesmo funda e enuncia.

\section{CONSTRUINDO A ANÁLISE}

Antes de iniciar o processo analítico a que me propus, reforço meu questionamento inicial planejado para este capítulo: comprovar a constituência do discurso teológico, incluindo-o na lista dos constituintes, conforme Maingueneau $(2000,2004,2006,2010,2015)$ e problematizar a inclusão do discurso religioso nesse quadro. Não se trata de questionar o programa de pesquisa iniciado por Maingueneau \& Cossutta (1995), mas de colaborar com o debate sobre a problemática dos discursos constituintes, no interior da AD. Outra coisa que é preciso deixar clara para os limites desse estudo: não quero contrapor discurso religioso e discurso teológico em função de seus conteúdos e de estratégias de produção enunciativo-discursiva. Seria um outro trabalho e demandaria adentrar ao campo da religiosidade e da Teologia. Ao pretender comprovar a constituência do discurso teológico, parto apenas de seus dispositivos enunciativos que se enlaçam, entre um modo de organização específico, um modo dizer e um modo de relacionar com a comunidade discursiva. O processo analítico que operacionalizo, como já disse, marca-se por uma metodologia discursiva de leitura, sem a pretensão de propor um estudo teológico, mas uma análise linguístico-discursiva.

Para uma análise criteriosa, devo considerar as condições sócio-históricas e culturais de produção do discurso em investigação. Em seguida, faz-se necessário ter em mente e recuperar as noções de discurso, objeto da $\mathrm{AD}$, por meio do qual fundamento a análise, a categoria discursos constituintes e a organização constitutiva do discurso teológico, considerando seu caráter auto e heterofundante, as suas implicações com o interdiscurso, a paratopia, o código linguageiro, a cenografia e o ethos discursivo. Julgo pertinente dizer, ainda, que apreendo a Teologia por sua discursividade e por sua pertinência em relação a mim como leitor de textos bíblicos. Aliás, essa é a motivação que me impulsiona a trazer para o interior da $\mathrm{AD}$ a questão da constituência do discurso teológico, cuja perspectiva metodológico-analítica me permite colocar em diálogo a Linguística e a Teologia, 
dentro de um cenário crítico, científico, pluralístico e líquido característico da contemporaneidade (BAUMAN, 2000).

Apresentado o percurso analítico que pretendo investigar, passo agora a operacionalizá-lo e, para tal, esclareço que o discurso As bodas de Caná da Galiléia está materializado na Bíblia, aqui considerada um archeion da produção verbal da sociedade. Encontra-se somente no evangelho de João, 2, 1-11 como uma manifestação linguística de uma prática discursiva. O evangelho de João, um dos doze discípulos de Jesus, é o quarto dos quatro evangelhos do Segundo Testamento e considerado por Beutler (2016) como o mais profundo e carregado de uma linguagem simbólica, cujo efeitos de sentido evidenciam uma estreita relação entre o humano e o divino e funciona como elo entre essas duas realidades, que juntas dão unidade ao texto. Ele está organizado em 21 capítulos e desenvolve uma perspectiva espiritual da vida de Jesus, secundarizando os eventos históricos, importantes para os outros evangelistas.

Embora se trate de um recorte analítico, o discurso que selecionei corresponde a uma unidade textual, cujos efeitos de sentido solicitam-me considerar a interação do linguístico com o histórico-cultural, para que eu o apreenda como discurso e mostre a historicidade dos fatos nele materializados e as particularidades de sua própria origem no interdiscurso. A forma de enunciação desse discurso revela a especificidade do ato autoral de João e a influência das condições sócio-histórico-culturais em que esse discurso fora produzido e a fala encenada. Os discursos em João sincronizam a vida de Jesus com as festas judaicas, pois que celebram acontecimentos salvíficos de Deus na caminhada de seu povo. Para alguns teólogos, entre eles, Beutler (2016), essa relação exige que se busque, nesse processo analítico, aspectos do ritual de contrato de casamento judaico e sua cerimônia, cujos efeitos de sentido simbolizam uma das dimensões da grandeza do relacionamento humano.

O objeto de minha análise se realiza em um gênero de discurso e em uma cena englobante, que definem o quadro cênico particular a um tipo de discurso. Isso se justifica, porque, mesmo não sabendo, a priori, o tipo de discurso implicado na produção enunciativa de sua materialidade simbólica, entendo que a cena englobante colabora no processo de negociação de efeitos de sentido e na apreensão do discurso pelo gênero, lugar onde seus actantes definem seus papéis. Entretanto, é a cenografia construída pelo enunciador que se configura e é com ela que me defronto. Na verdade, é a partir de enunciados descritos em suas condições sócio-históricas e culturais de produção e recepção que a cena vai sendo construída. Não existe, nesta perspectiva, um quadro construído a priori e independente, no interior do espaço enunciativo arquitetado pelo discurso. Todavia, a cenografia coexiste com o evento enunciativo e afasta o quadro cênico para instaurar-se na cena construída nela e por ela e que a legitima. 
A cenografia encena uma festa de casamento, em Caná da Galiléia, conforme os costumes e a cultura judaica. A festa de casamento era um evento grandioso, pois contava com a participação de muitas pessoas, durava vários dias e pautava-se na velha aliança. A região da Palestina era grande produtora de vinhos; por isso, essa bebida estava sempre presente nas refeições mas, nos casamentos, ela era servida em grande abundância, como um dom de Deus e símbolo de amor, alegria e prosperidade. Em um casamento, de forma alguma, poderia faltar vinho, o que causaria uma situação embaraçosa às famílias e aos convidados.

Outra característica que percebo na cenografia é que ela exibe uma série de informações inscrita em seu espaço enunciativo, onde participam os noivos, Jesus, sua mãe, os discípulos, o encarregado da festa e outros convidados das famílias de cada um dos noivos, cujas falas implicam uma situação de enunciação, que se valida na própria enunciação. Assim, o espaço enunciativo, o lugar, o evento, os actantes, a expectativa, o código linguageiro correlacionam-se às condições sócio-históricas e culturais de produção desse discurso, sobretudo, no que diz respeito à sua expressividade simbólica. Mesmo tomando todos esses elementos, é impossível caracterizar, ainda, esse discurso como teológico pois, para isso, se faz necessário que me situe para apreendê-lo, lembrando que o discurso interpela o co-enunciador em função do objetivo que ele visa a alcançar. Desse modo, esse discurso se materializa em um gênero, que define os papéis sociais que ele deve assumir. De qualquer forma, posso afirmar com Maingueneau (2015) que a cena englobante é a situação discursiva, que me autoriza alocar esse discurso no campo discursivo teológico e nele negociar efeitos de sentido.

Apresento a seguir o discurso de autoria de João, a fim de examinar, no funcionamento discursivo, os modos de apreensão desse tipo de discurso. Embora perpasse minha discussão, o fato de imputar a João a marca de autor, identificado como um eu na enunciação teológica, ligada à sua vida como produtor, a categoria de autoralidade precisa ser aprofundada. Lembro, ainda, que esse discurso se materializa linguisticamente e que o autor João se posiciona como uma figura contingente da enunciação. Em As bodas de Caná da Galiléia, é João que constrói a unidade sujeito Jesus, no mesmo instante em que Ele, Jesus, se instaura como um hiperenunciador, entidade transcendente que, em uma atitude paradoxal, valida os enunciados de João, autor empírico, que se assume como sujeito, para se igualar a outros sujeitos que interagem na cenografia.

1. No terceiro dia houve um casamento em Caná da Galiléia. A mãe de Jesus estava ali;

2. Jesus e seus discípulos também haviam sido convidados para o casamento. 
3. Tendo acabado o vinho, a mãe de Jesus lhe disse: "Eles não têm mais vinho".

4. Respondeu Jesus: "Que temos nós em comum, senhora? A minha hora ainda não chegou”.

5. Sua mãe disse aos serviçais: "Façam tudo o que ele lhes mandar".

6. Ali perto havia seis jarros de pedra, do tipo usado pelos judeus para as purificações cerimoniais, cada jarro com capacidade para setenta e cinco a cento e quinze litros.

7. Disse Jesus aos serviçais: "Encham os jarros com água”. E os encheram até à borda.

8. Então lhes disse: "Agora, tirem um pouco e levem-no ao encarregado da festa". Eles assim o fizeram,

9. e o encarregado da festa provou a água que fora transformada em vinho, sem saber de onde este viera, embora o soubessem os serviçais que haviam tirado a água. Então chamou o noivo

10. e disse: "Todos servem primeiro o melhor vinho e, depois que os convidados já beberam bastante, o vinho inferior é servido; mas você guardou o melhor até agora".

11. Este sinal miraculoso, em Caná da Galiléia, foi o primeiro que Jesus realizou. Revelou assim a sua glória, e os seus discípulos creram nele.

No primeiro recorte de fala, no terceiro dia, houve um casamento em Caná da Galiléia. A mãe de Jesus estava ali, o enunciador constrói uma sequência enunciativa introdutória, a fim de referendar o evento enunciativo, o casamento, por meio de dêixis temporal terceiro dia e espacial em Caná da Galiléia, situando a perspectiva de João no ato enunciativo. Ao acionar a dêixis temporal, no terceiro dia, o enunciador sinaliza proximidade em relação ao evento e provoca em minha memória duas referências: o regresso de Jesus à Galileia em companhia de alguns discípulos e a manifestação de sua glorificação plena pela primeira vez, após três dias de sua ressurreição. Esses mecanismos dêiticos estabelecem uma fronteira espaço-temporal, investem em uma cenografia que topicaliza o casamento como um evento, que o enunciador tematiza nesse ato enunciativo. Nesse sentido, por meio do tema casamento, João projeta, no funcionamento discursivo, as recorrências linguísticas que afiançam os efeitos de sentido do texto, confirmando-se que o tema aqui tem um caráter abstrato.

O efeito de sentido investido em casamento evidencia não somente o tema em torno do qual o enunciador projeta o discurso e coloca-o em funcionamento, mas também remete à imagem de casamento como símbolo de aliança entre Deus 
e seu povo, asseverando a impossibilidade de dissociar uma interdiscursividade, que ocupa a cenografia, para lembrar que a união com Deus dá fruto, gera a bênção e a festa. Nesse espaço discursivo, o enunciador coloca em cena um interdiscurso, um conhecimento da memória que se reatualiza nessa enunciação e leva-me a buscar nos atos de fala que o funda, que Deus, após a criação do homem e da mulher, cria o casamento e cria para si uma esposa, conforme consta, por exemplo, no Primeiro Testamento, em Isaias 54,5, porque o teu Criador é o teu marido; o Senhor dos Exércitos é o seu nome; e o Santo de Israel é o teu Redentor; que é chamado o Deus de toda a terra. Essa forma de o enunciador inserir o interdiscurso intradiscursivamente é própria do discurso constituinte, na medida em que ele, claro ao enunciador, pois é do thesaurus, se torna reatualizado e relembrado pelo próprio discurso, ou seja, pelo discurso que ele mesmo é a fonte e faz circular. Este recorte funciona, então, como um orientador enunciativo, convoca o co-enunciador à compreensão do discurso e, por um procedimento interdiscursivo aponta que o discurso sobre o qual ele se constitui é ele mesmo, um discurso primeiro, além do qual só há o indizível, o Absoluto (MAINGUENEAU, 2000).

Ainda no primeiro recorte, apreendo o enunciado A mãe de Jesus estava ali. Aqui há a instauração de um processo discursivo, que mobiliza uma relação de parentesco com a mãe de Jesus, cujo nome é apagado, de forma a qualificá-la objetivamente e reconstituir uma referência familiar, a partir de um efeito de sentido real. Assim, o enunciador atribui a ela a missão materna nos planos humano e espiritual estendida também aos discípulos de Jesus. Por isso, a expressão dêitica ali, parece criar uma delimitação espacial, mas promove uma demarcação que extrapola a enunciação, como se fosse ali e em outros lugares. O enunciador, por meio desse enunciado, mostra seu posicionamento e constrói uma identidade discursiva para a mãe de Jesus, confirmando a transcendência de sua maternidade. Este recorte introdutório funciona, por conseguinte, como uma chave para a compreensão do discurso, pois sua inteligibilidade pelo co-enunciador está diretamente ligada a uma competência linguístico-discursiva e simbólica. Isso mostra que valores, crenças e outros posicionamentos, reveladores do conhecimento do enunciador em interação com o co-enunciador decorrem em função das condições sócio-histórico-culturais de produção do discurso e do momento de sua enunciação.

No recorte 2, Jesus e seus discípulos também haviam sido convidados para o casamento, como me é dado a ver, o enunciador constrói a cenografia pela instituição de um espaço enunciativo, que integra, no casamento, Jesus e seus discípulos. Assim, as ações que se desenrolarão nesse evento preveem a participação de actantes implícitos e explícitos, que desempenham papéis específicos na trama da narrativa enunciada. Vale ressaltar, ainda, que a mãe de Jesus foi inserida na 
cenografia no primeiro recorte, Jesus e seus discípulos arrolados apresentam-se aqui na cenografia como convidados e assumem papéis essenciais no discurso, principalmente em razão das relações que se estabelecerão entre eles. O investimento desses actantes nessa cenografia é um índice, que me possibilita observar iniciada a narrativa no espaço cênico do casamento. Assim, João mostra sua autoralidade, assumida por uma condição paratópica, ao se inscrever em uma situação enunciativa que é e não é própria, mas que o autoriza, embora se distancie de sua fala, para integrar a de um hiperenunciador, que a garante. $\mathrm{O}$ discurso, em análise, coloca em movimento não apenas os actantes, que manifestam papéis sociodiscursivos geradores dos enunciados, mas também e, principalmente, o hiperenunciador, cuja identidade discursiva mobiliza o aparelho enunciativo e domina as condições externas e internas à narrativa, pois a "narrativa é igualmente um trabalho de legitimação de sua própria cena de enunciação" (MAINGUENEAU, 2006, p. 65). Com isso, esse discurso situa-se em uma localização paratópica, posto que visa a explicar suas condições de criação, incluindo a sua própria, como acontece com os discursos constituintes.

No terceiro recorte, Tendo acabado o vinho, a mãe de Jesus lhe disse: "Eles não têm mais vinho", seguem os desdobramentos das ações que foram introduzidas na cenografia, que se propõem como uma ancoragem para legitimar o discurso. Ao acabar o vinho, o enunciador movimenta na cenografia a mãe de Jesus, que entra em cena para informá-lo daquela ocorrência, temendo um constrangimento daquela situação e procura solucioná-la. Aqui, preciso mobilizar, na memória discursiva, um sentido já pré-construído que resgata o vinho como símbolo de um dom de Deus para a alegria e prosperidade dos noivos e de sua família. Além disso, mostrar que, no Primeiro Testamento, há interdiscursos reveladores de alteridade discursiva, localizáveis, por exemplo, em Salmos 104,15; Juízes 9,13; Cântico dos Cânticos 1,2 e Isaias 25,6, onde o vinho é concebido como símbolo do banquete messiânico da salvação de Deus. É muito importante reconhecer o estatuto simbólico do discurso teológico e o papel do investimento no interdiscurso, a fim de depreender a importância do vinho, sobretudo, no evangelho de João e, particularmente no texto em análise. De fato, esse investimento em enunciados do Primeiro Testamento representa não somente o reconhecimento do texto-fonte, mas a possibilidade que o enunciador faz em reatualizá-lo no intradiscurso, como em Amós, 9, 13-15, que afirma: a abundância de vinho é o sinal do tempo messiânico da salvação.

$\mathrm{Na}$ verdade, é o vínculo materno que revela o desejo da mãe de Jesus em buscar uma atitude do filho para a solução da falta de vinho, considerando o conhecimento que tinha dele, a partir de um laço fundamental em que ela consegue associar uma essência divina e humana. Por isso, a mãe encontraria, no filho Jesus, uma solução da ordem do divino, próprio da divindade de Jesus e outra da ordem do humano, própria da pessoa de Jesus. 
No quarto recorte, Respondeu Jesus: Que temos nós em comum, senhora? A minha hora ainda não chegou, o enunciador traz à cenografia um evento comunicativo, em que Jesus é interpelado por sua mãe, para a realização de uma ação interventora. O questionamento de sua mãe desempenha uma função argumentativa, que engendra um efeito de sentido possível de solução do impasse e cria uma situação enunciativa inscrita por uma subjetividade, que lhe assegura a existência na cenografia e um benefício aos noivos e ao casamento. Jesus com sua resposta argumenta a minha hora ainda não chegou e, por esse enunciado, posiciona-se como um sujeito magistral, na medida em que dirige-se tanto à sua mãe quanto aos outros actantes daquela cenografia e cujo efeito de sentido o indicia como aquele que pode controlar as ações humanas e divinas, que ali se desenrolam, para se constituir como instância de condição e de criação do discurso.

De fato, a existência do sujeito Jesus supõe ao mesmo tempo uma existência humana e outra divina impossível de confundi-las, de onde decorre a necessidade de jogar com esse pertencimento - não-pertencimento para afiançar sua existência. Nesse sentido, Jesus pertence plenamente à condição humana e à condição divina, mantendo-se no espaço humano-divino em um pertencimento paratópico explicável somente por ele mesmo. Essa consideração atesta a constituência teológica desse discurso, particularmente, ao recuperar, em Maingueneau, a categoria paratopia como uma condição desse discurso e da condição de seu ato criativo. Com isso, podemos associar esse recorte aos anteriores e identificar a manifestação do sujeito Jesus, reagindo frente a uma situação enunciativa estritamente humana da parte de sua mãe. No mesmo instante em que regras sociais, valores e posicionamentos sustentam a reação da mãe de Jesus, abrem-se seus olhos para a compreensão do enunciado proferido por seu filho: a minha hora ainda não chegou. Esse enunciado e o posicionamento nele materializado criam um efeito de sentido-chave para a coerência do discurso, além de mostrar um ethos que assegura sua vontade de intervenção direta ou indireta naquela situação enunciativa.

$\mathrm{Na}$ verdade, Jesus queria suscitar uma reação, colocando, de maneira explícita, um argumento que justificasse a ocorrência de sua intervenção. Afinal, sua mãe deveria entender que, a partir de então, o Pai conduziria o ministério de seu filho e não ela, sua mãe. O movimento discursivo dessa cenografia leva o enunciador a investir em um ethos discursivo, cujo modo de dizer implica um modo de ser e argumentar. A cenografia mostra Jesus se legitimando para deslegitimar a parcialidade do enunciado de sua mãe. Em suma, esse discurso apresenta traços de discurso constituinte, principalmente se considerarmos o investimento feito na constituição da cenografia, na condição paratópica do hiperenunciador e no ethos discursivo. 
No quinto recorte, sua mãe disse aos serviçais: "Façam tudo o que ele lhes mandar". Esse ato de produção discursiva da mãe de Jesus, parece-me carregado de uma força argumentativa, que posiciona sua interação com os serviçais. $\mathrm{Ou}$ seja, a mãe de Jesus, inscrita na cenografia, confirma sua participação naquele banquete nupcial e é reconhecida por sua relação com os serviçais "façam tudo o que ele lhes mandar”. Este enunciado proferido pela mãe de Jesus, faz com que o enunciador, João, esqueça seu posicionamento discursivo e crie um efeito de ilusão, por meio de um interdiscurso buscado no Primeiro Testamento, onde o povo de Israel, no monte Sinai, se compromete às promessas de aliança, conforme consta em “Quanto o Senhor disse, nós o faremos!” (Êxodo 19,8; 24, 3.7). Esse interdiscurso funciona, então, como um espaço de retomada de sua própria fonte, mas não reduzida a somente isso, pois ela se reatualiza ali intradiscursivamente. Nesse sentido, as condições sócio-históricas e culturais de produção e os interdiscursos tornam-se constitutivos do modo de dizer desse discurso e possibilita-me demarcar um aspecto de sua constituência, ou seja, por meio da rememoração do interdito, ele próprio se reconhece como fonte e origem de si mesmo.

No sexto recorte, Ali perto havia seis jarros de pedra, do tipo usado pelos judeus para as purificações cerimoniais, cada jarro com capacidade para setenta e cinco a cento e quinze litros. Nesse recorte, destaco, na cenografia, a ocorrência de um plano descritivo-argumentativo para identificar os elementos ali relacionados: seis jarros de pedra, do tipo usado pelos judeus para as purificações cerimoniais. O número seis evoca na memória discursiva o Talmude, que regulamentava serem tais jarros de pedra, para garantir a pureza da água. Além disso, o enunciador desperta uma atitude interdiscursiva, que carrega uma voz enunciativa justificada pela simbologia do número seis, chamado o número do homem (Apocalipse 13,18), evocado, ainda, de Gêneses 1,27,31. O homem foi criado no sexto dia. De fato, a ativação desses interdiscursos torna a enunciação mais produtiva, na medida em que leva o co-enunciador a acompanhar os movimentos enunciativos que se desenrolam na cenografia. Dessa maneira, o enunciador busca na memória do co-enunciador o reconhecimento do investimento que operou com o interdiscurso, a fim de legitimá-lo, validando sua enunciação, pela reformulação do discurso-fonte com vistas a adequá-lo às necessidades enunciativas atuais de seu enunciado. Por isso, compreendo que a convergência dos interdiscursos para a cenografia construída nesse discurso, deslocado do discurso-primeiro, não somente os reatualiza, mas constrói novos efeitos de sentido, em função das particularidades requeridas por esse discurso. Na verdade, essa operação é complexa, pois se faz necessário distinguir o interdiscurso em sua constituição na origem e, ainda, sua conservação nesse discurso, isto é, no discurso segundo.

No sétimo recorte, Disse Jesus aos serviçais: "Encham os jarros com água”. E os encheram até à borda, os enunciados aqui materializados instituem uma cenografia, como em qualquer situação de comunicação, que instaura o sujeito 
enunciador, Jesus, no mesmo instante em que, por um processo intersubjetivo, instala seus co-enunciadores, os serviçais, constituindo uma relação discursiva entre eles. A enunciação encena o pedido de Jesus e o imediato atendimento dos serviçais, anteriormente alertados pela mãe de Jesus. Essa cenografia é indispensável para ligar os fatos: falta de vinho - pedido a Jesus por sua mãe - alerta aos serviçais pela mãe de Jesus - ordem dada por Jesus - atendimento a Jesus pelos serviçais.

A água, na cultura judaica da época, era tida como um símbolo da Torá, como também os jarros, que lembram as tábuas de pedra em que foi escrita Lei (Êxodo 31, 18; 32, 15). Nesse sentido, o enunciador utiliza o Primeiro Testamento como uma interligação implícita que traz da memória dados das condições sócio-históricas e culturais de produção, que se interligam a esse discurso. Para esclarecer a afirmação, ressalto que o interdiscurso estabelece aqui uma relação entre um texto-fonte, linguisticamente materializado no Primeiro Testamento, ou seja, ele interpela sua própria origem por meio de uma historicidade que legitima a si mesmo. É exclusividade dos discursos constituintes autorizarem-se a si mesmos; por isso, o discurso de João que aqui estudo, conquanto seja do Segundo Testamento, propõe-se ligado a uma fonte legitimadora que é ele mesmo. Por isso, é constituinte, uma vez que esse discurso se constitui por um investimento interdiscursivo com sua própria origem.

Em síntese, os serviçais, preocupados com a falta do vinho, ao se depararem com a ordem de Jesus, buscam atendê-lo na expectativa de verem aquela situação resolvida. Jesus, insere-se à comunidade discursiva dos sujeitos que se movem naquela cenografia e engaja-se como membro dela com o intuito de resolver o impasse ocorrido pela falta de vinho.

Sendo o discurso um lugar de interação, agora, reúno os recortes 8 a 10, agrupados devido à sua unidade na/pela situação de interlocução entre os sujeitos João, Jesus, os serviçais e o encarregado pelo casamento, que se movimentam na cenografia instaurada. A encenação está assim enunciada: 8. Então lhes disse: "Agora, tirem um pouco e levem-no ao encarregado da festa". Eles assim o fizeram, 9 e o encarregado da festa provou a água que fora transformada em vinho, sem saber de onde este viera, embora o soubessem os serviçais que haviam tirado a água. Então chamou o noivo 10 e disse: "Todos servem primeiro o melhor vinho e, depois que os convidados já beberam bastante, o vinho inferior é servido; mas você guardou o melhor até agora". A cenografia encena uma situação comunicativa em que Jesus, após, pedir aos serviçais que enchessem os jarros, tirassem um pouco de seu conteúdo e levassem ao encarregado da festa. Tendo provado da bebida, o encarregado, chamou o noivo, para lhe dizer que todos servem primeiro o melhor vinho e, depois que os convidados já beberam bastante, o vinho inferior é servido; mas você guardou o melhor até agora. 
Nessa cenografia, movimentam-se João, como enunciador-narrador, Jesus que, por meio de discurso direto toma a palavra e o encarregado da festa, que se manifesta de forma enunciativa. A forma como se organizam os enunciados confere-lhes uma configuração particular e leva-me a construir diferentes efeitos de sentido, principalmente, se relacionar a necessidade da água para a vida humana e o vinho como expressão simbólica da abundância do banquete e a alegria da festa. No casamento, não poderia faltar o vinho. Assim, transformando em vinho a água dos jarros de pedra, Jesus transforma a Lei de Moisés. Por esse recorte finalizador, de um lado, observo que a mãe de Jesus simboliza Israel que sentiu falta do vinho, mas também aquela que percebe a necessidade do povo, e mais ainda, aquela que espera pelo Reino de Deus. Por outro lado, o encarregado da festa simboliza os judeus, que estão preocupados com a água para purificação, ou seja, os dirigentes judeus, que buscam manter a antiga aliança, que está desgastada. O encarregado da festa prova o vinho, mas se espanta, não sabe de onde vem vinho tão bom e não reconhece Jesus.

No último recorte, Este sinal miraculoso, em Caná da Galiléia, foi o primeiro que Jesus realizou. Revelou assim a sua glória, e os seus discipulos creram nele. Esse milagre de Jesus ocorre em um casamento, pois queria enunciar, por meio de uma linguagem simbólica, a restauração de uma nova aliança com Israel em Jesus e por Jesus. Esse evento restaura, por conseguinte, a comunhão de Deus com seus escolhidos, entre eles, os discípulos, que são judeus, que são israelitas e estavam no casamento. Neste sentido, os doze discípulos de Jesus simbolizam as doze tribos de Israel, conforme consta no segundo recorte dessa análise Jesus e seus discípulos também haviam sido convidados para o casamento. Não só Jesus era parte importante, mas os discípulos eram convidados especiais neste casamento. O milagre de Caná é o sinal de um novo tempo: rompida a antiga aliança, instaura uma nova aliança em que Jesus transforma a Lei de Moisés no Evangelho, confirmando que a graça e a verdade vêm por meio d’Ele.

\section{CONSIDERAÇÕES FINAIS}

Ao longo deste capítulo, busquei refletir sobre a possibilidade de inserção do discurso teológico no quadro dos discursos constituintes, questionando o fato de o discurso religioso ter sido incluído nessa categoria. Parti dos fundamentos teórico-metodológicos da Análise do Discurso de linha francesa, apoiando-me na hipótese de pesquisa sobre os discursos constituintes, conforme proposto por Maingueneau (2000, 2004, 2006, 2008, 2015). No entanto, o problema de pesquisa que apresento não pretende distinguir discurso religioso e discurso teológico, embora o religioso se fundamente no teológico. Na verdade, o discurso religioso, constrói-se sobre o teológico, assumindo-o interdiscursivamente, na 
medida em que, em seu funcionamento, ressignifica-o, ampliando e delimitando possíveis interações.

Em função disso, no percurso do capítulo, caracterizei o discurso religioso como um discurso institucional, visto que não se funda a si mesmo, propõe uma relação de poder, sustenta-se pelo controle e imposição sobre os fiéis e constitui um quadro de referência obrigatório aos posicionamentos ideológicos. Isso me fez argumentar que o discurso teológico, ao contrário, encena particularidades enunciativas, é autofundante, organiza-se por meio de uma linguagem simbólica, por estruturas míticas de natureza ontológica incontestáveis, que validam a si próprias e outros tipos de discurso, garantindo a si mesmo uma legitimidade fundante. Por isso, sob a luz das reflexões de Maingueneau, reconheço que cada um desses discursos se define por propriedades que garantem suas identidades e evidenciam seus espaços discursivos.

Uma vez feitas essas considerações, para inserir o teológico no quadro dos discursos constituintes, selecionei da Bíblia, aqui considerada um archeion da produção verbal da sociedade, o discurso As bodas de Caná da Galiléia, materializado, no Segundo Testamento, no evangelho de João, 2, 1-11 como uma manifestação linguística de uma prática discursiva. O evangelho de João, um dos doze discípulos de Jesus, é o quarto dos quatro evangelhos e considerado como o mais profundo e carregado de uma linguagem simbólica.

Meu trabalho de leitura crítico-reflexiva do discurso de As bodas de Caná da Galileia mereceu um tratamento discursivo, pois o considerei em sua materialidade linguística, em sua forma de ação sobre o outro, além de seu caráter interativo em meio às suas condições sócio-histórico-culturais de produção. No processo analítico, verifiquei a relação interdisciplinar da Análise do Discurso com a Teologia, de cujas abordagens destacam-se aspectos de instauração discursiva, sem contudo, ter a pretensão de elaboração de uma leitura hermenêutica ou exegética, dado que esse trabalho se insere na Linguística, mais particularmente, na Análise do Discurso de linha francesa. As unidades selecionadas para a análise foram o interdiscurso, o código linguageiro, a cenografia e o ethos discursivo, porque se articulam, para suscitar a adesão do co-enunciador, ao inscrevê-lo em uma instituição discursiva e funcionam como um gatilho para a comprovação do teológico como discurso constituinte.

Para comprovar a constituência do discurso teológico, a partir do discurso que analiso, primeiramente, ressalto que ele está materializado no archeion, na Bíblia, lugar de funcionamento da autoridade, em nossa cultura. E para isso, reforço com um argumento retirado do próprio Maingueneau (2008, p.39), quando postula que o "archeion associa assim intimamente o trabalho de fundação no e pelo discurso, a determinação de um lugar associado a um corpo de enunciadores consagrados e uma gestão de memória” . 
Embora reconheça a profundidade do tema, os simbolismos do código linguageiro utilizado por João, o posicionamento de fé imposto por meu lugar de fala, além dos limites estabelecidos pela metodologia de leitura assumida, percebi que o discurso As bodas de Caná da Galileia parte de práticas discursivas, que se entrelaçam na relação humano-divino, com o objetivo de emoldurar uma situação enunciativa paratópica de seu processo criador. O projeto que entendo como uma metodologia crítico-reflexiva de leitura desse discurso fez-me, sobretudo, valorizar a cenografia como um pano de fundo, onde o enunciador cria uma encenação que tem por função, ao mesmo tempo, legitimá-lo e validá-la. Na cenografia, associaram-se o evangelista João, que se investiu ora de metaenunciador, a fim de organizar a enunciação, ora como uma instância sujeito narrador, para pôr em movimento Jesus, a mãe de Jesus e o encarregado pela festa, em uma espécie de um relacionamento paradoxal.

O processo analítico revelou-me a complexidade desse tipo de discurso, que abrange um universo humano e divino em que os efeitos de sentido decorrem de competências linguísticas, simbólicas, culturais, interdiscursivas e do posicionamento de fé, que se apresentam como ações complexas para serem gerenciadas, particularmente, quando observo a relação entre o enunciador/autor/metaenunciador, João e o hiperenunciador, Jesus em sua dimensão paratópica. Considerando, portanto, a forma como esse discurso se instaura, o modo como constrói sua própria origem pelo interdiscurso, além de sua organização e abertura a outros discursos, que se fundam nele e, por isso, são atravessados por ele, parece-me que não há motivo para questionar a sua constituência e muito menos não incluí-lo no quadro inicial dos discursos constituintes, conforme proposto por Maingueneau \& Cossutta (1995). Tenho certeza de que muitas outras questões ficaram abertas, mas devem ser retomadas em outras reflexões.

\section{REFERÊNCIAS}

BAUMANN, Zygmunt. O mal estar da pós-modernidade. Rio de Janeiro: Zahar, 2000. BEUTLER, Johanes. Evangelho segundo João. Comentário (BL - 70). Loyola: São Paulo, 2016.

BÍBLIA DE JERUSALÉM. São Paulo: Paulus, 1996.

BRANDÃO, Helena HN. Introdução à análise do discurso. $3^{\mathrm{a}} \mathrm{ed}$. Campinas: UNICAMP, 2012.

BOURDIEU, Pierre. O poder simbólico. Trad. Fernando Tomaz. Lisboa: Difel, 1989. . A economia das trocas simbólicas. São Paulo: Perspectiva, 2013.

CHARAUDEAU, Patrick. Dize-me qual é teu corpus, eu te direi qual é a tua problemática. Revista Diadorim. Universidade Federal do Rio de Janeiro, volume 10, dezembro, 2011. 
CHARAUDEAU, Patrick \& MAINGUENEAU, Dominique. Dicionário de análise do discurso. São Paulo: Contexto, 2008.

DELRUELLE. Edouard. Metamorfoses do sujeito. A ética filosófica de Sócrates a Foucault. Lisboa: Instituto Piaget. 2004.

DODD, C.H. La tradition historique du quatrième évangile. Paris: Édition du Cerf, 1987.

DURKHEIM, Émile. As formas elementares da vida religiosa. São Paulo: Martins Fontes, 1996.

GABUS. Jean-Paul. Critique du discours théologique.Paris: Delachaux \& Niestlé, 1977.

FANTI, Maria da Glória di \& BARBISAN, Leci Borges. Enunciação e Discurso - tramas do sentido. São Paulo: Contexto, 2012.

FOUCAULT, Michel. A ordem do discurso. São Paulo: Loyola, 1998.

GIDDENS, Anthony. Sociologia. Porto Alegre: Artmed, 1994.

. Modernidade e identidade. Rio de Janeiro: Jorge Zahar, 2003a.

- Mundo em descontrole: o que a globalização está fazendo de nós. 3 ed. Rio de Janeiro: Record, 2003b.

. A Constituição da Sociedade. Tradução de Álvaro Cabral. - São Paulo: Martins, 2006.

GLOCK, C.Y. \& STARK, R. Religion and Society in Tension. Chicago: Rand McNally, 1965

KRIEG-PLANQUE, Alice. Analyser les discours institutionnels, Paris: Armand Colin, 2014.

LIBANIO, J.B.\& MURAD, Afonso. Introdução à teologia - perfil, enfoques, tarefas. São Paulo: Loyola, 2005.

MAINGUENEAU, Dominique. Le contexte de l'œuvre littéraire: Enonciation, écrivain, société. Paris: Dunod, 1993.

MAINGUENEAU, Dominique. L'analyse des discours constituants. In: MARI, Hugo et al. (org.). Fundamentos e dimensões da análise do discurso. Belo Horizonte: Carol Borges, 1999.

. Analisando discursos constituintes. GELNE, v.2, n.2, 2000

. Discurso literário: Paratopia e cena de enunciação. Paris: Armand Colin, 2004

. L'énonciation philosophique comme institution discursive. In: Langages, ano

29, n. 119, 1995. L'analyse du discours philosophique. p. 40-62.

. Discurso Literário. São Paulo: Contexto, 2006.

. Análise do Discurso e suas fronteiras, Revista Matraga, v.14, número 20. São

Paulo, 2007.

. Cenas da enunciação. São Paulo: Parábola, 2008.

. La difficile émergence d'une analyse du discours religieux, Langage et société, 4, n. 130, 2009.

. Doze conceitos em Análise do Discurso. São Paulo: Parábola, 2010. 
. Clareza do texto, discursos constituintes e quadro hermenêutico. 19 Revista do Programa de Pós-Graduação em Letras da Universidade de Passo Fundo - v. 8 - n. 1 - p. 11-19 - jan./jun. 2012.

. Discurso e análise do discurso. São Paulo: Parábola, 2014.

O que pesquisam os analistas do discurso. Revista da ABRALIN, v.14, n.2, p. 31-40, jul./dez. 2015a. $2015 b$

. La Philosophie comme instituition discursive. Limonges: Lambert-Lucas, . Retorno crítico sobre o ethos. In: BARONAS, R.L.; MESTI, P. C.; CARREON, R. O. Análise do Discurso: entorno da problemática do ethos, do político e de discursos constituintes. Campinas, SP: Pontes, 2016a

Autoralidade e Pseudonomia. In: Revista da ABRALIN, v.15, n.2, p. 101-117, jul./dez. 2016b

MAINGUENEAU, Dominique. \& COSSUTTA Frederic. L'analyse des discours constituants. In: Langages, n. 29, n.117, 1995. p. 112-125.

MENDONÇA, A.G. A experiência religiosa e a institucionalização da religião. Estudos Avançados, v.18, n.52, p.29, 2004.

NASCIMENTO, Jarbas Vargas. O Discurso religioso católico: um estudo do rito matrimonial católico. São Paulo: EDUC, 1993.

NASCIMENTO, Jarbas Vargas. et alii. A parábola do filho pródigo. São Paulo: LPB, 2009.

NASCIMENTO, Jarbas Vargas \& FERREIRA, Anderson. Discurso e Cultura. Volume I. São Paulo: Blucher, 2018.

NASCIMENTO, Jarbas Vargas \& FERREIRA, Anderson. Discurso e Cultura. Volume II. São Paulo: Blucher, 2019.

NOGUEIRA, P.A.S. (Org.). Linguagens da religião: desafios, métodos e conceitos

Centrais. São Paulo: Paulinas, 2012a. p.9-1

MCCARYHEY, N. Sociologia. São Paulo: Artmed, 1994.

MORAES, Marcos Antonio de, MARRAS, Stélio \& SIMIONI, Ana Paula Cavalcanti. Disciplinar, inter-trans-multi-pós-disciplinar. In: Revista do Instituto de Estudos Brasileiros. no. 64 São Paulo, May/Aug. 2016, p.1.

ORLANDI, Eni Puccinelli. A linguagem e seu funcionamento: as formas do discurso. Campinas: Pontes, 1983.

ORLANDI, Eni Puccinelli. Análise de discurso: princípios e procedimentos. Campinas: Pontes, 1999.

PAES, Marilena Leite. Arquivo: teoria e prática. Rio de Janeiro: Fundação Getúlio Vargas, 2002.

POSSENTI, Sírio. Os limites do discurso. Ensaios sobre discurso e sujeito. Curitiba: Criar Edições, 2002. 
SMITH, F. Leitura significativa. Tradução Neves, B. A. Porto Alegre: Editora Artes Médicas Sul Ltda.,1999.

PIAGET, Jean. Seis estudos de psicologia. 4. ed. Tradução Maria Alice Magalhães D’Amorim; Paulo Sérgio Lima Silva. Rio de Janeiro: Forense, 1971.

SALES, Franciele E. \& HAETINGER, Matheus. A religião como instituição social. In:

https://prezi.com/ca4bal5dfjim/a-religiao-como-instituicao-social/. Acesso em 20 de janeiro de 2020.

SCOTT, John. Sociological theory. Contemporary debates, Cheltenham, Edward Elgar Publishing, 2006.

TILLIC, Paul. Teologia sistemática. São Leopoldo: Sinodal, 2005. . Teologia da cultura. São Paulo: Fonte, 2009.

VEBLEN, T. Teoria da classe ociosa: um estudo econômico das instituições. São Paulo: Abril Cultural, 1993. 